This document is confidential and is proprietary to the American Chemical Society and its authors. Do not copy or disclose without written permission. If you have received this item in error, notify the sender and delete all copies.

\title{
Pelagic vs coastal - Key drivers of pollutant levels in Barents Sea polar bears with contrasted space-use strategies
}

\begin{tabular}{|r|l|}
\hline Journal: & Environmental Science \& Technology \\
\hline Manuscript ID & es-2019-04626b.R1 \\
\hline Manuscript Type: & Article \\
\hline Duthor: & $\mathrm{n}$ /a \\
\hline Complete List of Authors: & $\begin{array}{l}\text { BLEVIN, Pierre; Norwegian Polar Institute, } \\
\text { Aars, Jon; Norsk Polarinstitutt } \\
\text { Andersen, Magnus; Norsk Polarinstitutt } \\
\text { Blanchet, Marie-Anne; UiT Arctic University of Norway } \\
\text { Hanssen, Linda; NILU, MILK } \\
\text { Herzke, Dorte; NILU, Environmetal Chemistry } \\
\text { Jeffreys, Rachel; University of Liverpool } \\
\text { Nordøy, Erling; UiT Arctic University of Norway } \\
\text { Pinzone, Marianna; University of Liege } \\
\text { De la Vega, Camille; University of Liverpool } \\
\text { Routti, Heli; Norsk Polarinstitutt, }\end{array}$ \\
\hline & \\
\hline
\end{tabular}

\section{SCHOLARONE ${ }^{\text {M }}$ Manuscripts}




\section{Pelagic vs coastal - Key drivers of pollutant levels in Barents Sea}

\section{2 polar bears with contrasted space-use strategies}

3

6

7

8

9

Pierre Blévin ${ }^{*}$, Jon Aars ${ }^{*}$, Magnus Andersen", Marie-Anne Blanchet ${ }^{\ddagger}$, Linda Hanssen ${ }^{\perp}$, Dorte Herzke $^{\perp}$, Rachel Jeffreys ${ }^{\#}$,Erling S. Nordøy', Marianna Pinzone ${ }^{\square}$, Camille de la Vega Routti

${ }^{\dagger}$ Norwegian Polar Institute, Fram Centre, Tromsø, Norway

$\$$ The Arctic University of Norway, Norwegian College of Fishery Science, Tromsø, Norway

${ }^{\perp}$ Norwegian Institute for Air Research, Fram Centre, Tromsø, Norway

\# University of Liverpool, School of Environmental Science, Liverpool, United Kingdom

'The Arctic University of Norway, Department of Arctic and Marine Biology, Tromsø, Norway $\square$ Laboratory of Oceanology, Department of Biology, Ecology \& Evolution, University of Liège, Liège, Belgium

\section{*Corresponding author}

Pierre Blévin

Norwegian Polar Institute, Fram Centre

Tromsø, Norway

"blevin.pierre@gmail.com 


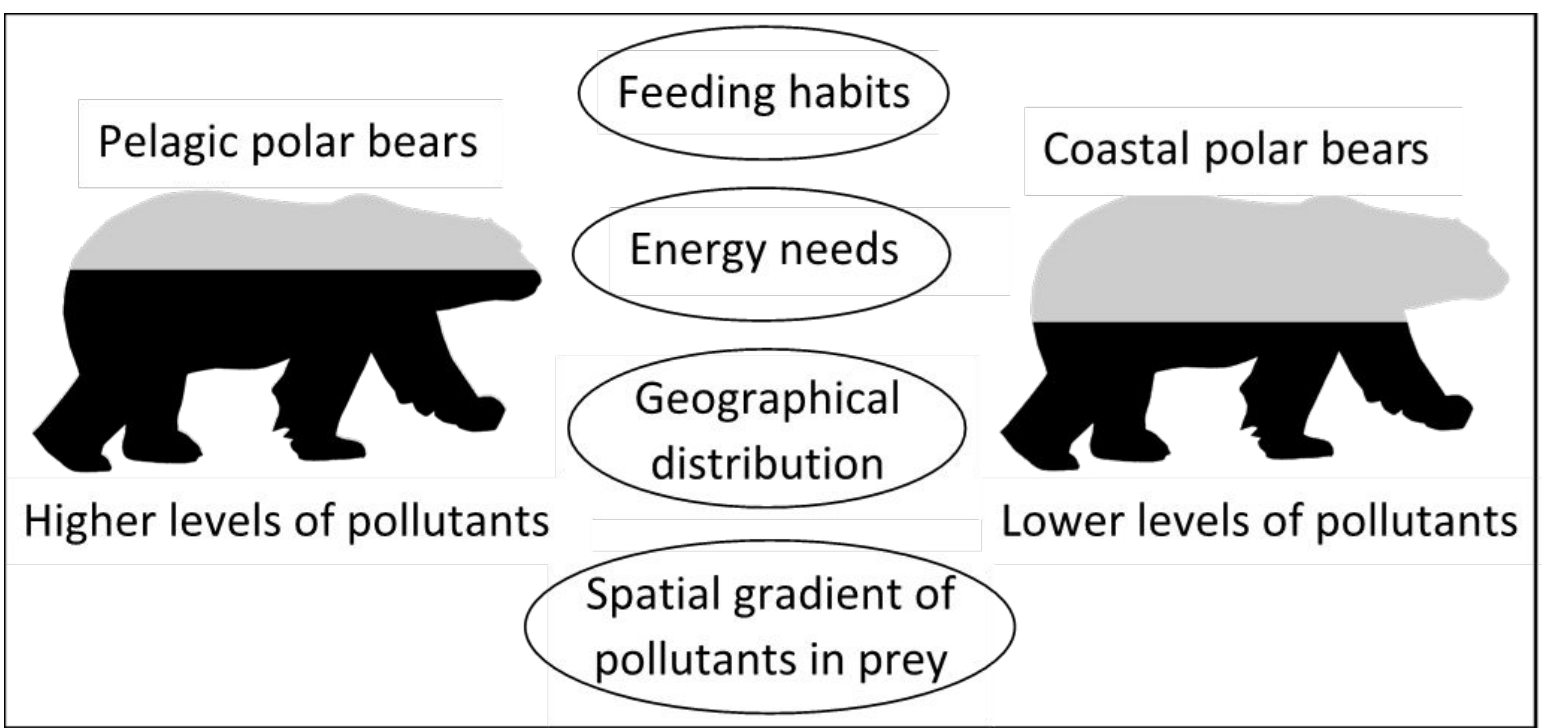


In the Barents Sea, pelagic and coastal polar bears are facing various ecological challenges that may explain the difference in their pollutant levels. We measured polychlorinated biphenyls, organochlorine pesticides, polybrominated diphenyl ethers in fat, and perfluoroalkyl substances in plasma in pelagic and coastal adult female polar bears with similar body condition. We studied polar bear feeding habits with bulk stable isotope ratios of carbon and nitrogen. Nitrogen isotopes of amino acids were used to investigate their trophic position. We studied energy expenditure by estimating field metabolic rate using telemetry data. Annual home range size was determined and spatial gradients in pollutants were explored using latitude and longitude centroid positions of polar bears. Pollutant levels were measured in harp seals from the Greenland Sea and White Sea - Barents Sea as a proxy for a West-East gradient of pollutants in polar bear prey. We showed that pelagic bears had higher pollutant loads than coastal bears because: (1) they feed on higher proportion of marine and higher-trophic level prey, (2) they have higher energy requirements and higher prey consumption, (3) they forage in the marginal ice zones, and (4) they feed on prey located closer to pollutant emission sources/ transport pathways. 


\section{Introduction}

Persistent organic pollutants (POPs) are transported to remote places such as the Arctic through air and ocean currents in addition to river outflows ${ }^{1-6}$. Species at the top of the food web with lipid-rich diets, such as polar bears (Ursus maritimus), bioaccumulate relatively high concentrations of POPs $^{7-11}$. Concomitantly, Arctic sea-ice is declining at an unprecedented rate $^{12}$, and loss of sea ice due to climate change is one of the greatest threats to polar bears ${ }^{13,14}$. Cumulative stress from habitat loss, reduced food availability and exposure to pollutants could be of high significance in some polar bear populations ${ }^{15-17}$.

The Barents Sea polar bears experience high exposure to POPs compared to several other subpopulations ${ }^{18,19}$. In particular, concentrations of perfluoroalkyl substances (PFASs), mainly perfluoroalkyl acids that bind to proteins, have been detected at high concentrations in Barents Sea polar bears ${ }^{19,20}$. PFASs contain both emerging and legacy compounds and are broadly present in various consumer products, because of their surfactant and water repellent properties $^{21-23}$. The polychlorinated biphenyls (PCBs) and organochlorine pesticides (OCPs), followed by the polybrominated diphenyl ethers (PBDEs), are quantitatively the most abundant lipophilic compounds detected in Barents Sea polar bears ${ }^{24}$. PCBs and OCPs were extensively used in the past in various industrial and agricultural applications, and their use had been gradually regulated since 1970. PBDEs have been largely employed as brominated flame retardants and their regulation has been ongoing for the last decade. Meanwhile, Arctic sea ice, which represents the main polar bear habitat for foraging, travelling and mating ${ }^{14,25,26}$, is declining at the fastest recorded rate in the Barents $\mathrm{Sea}^{27}$. This polar bear subpopulation, shared between Norway and Russia, is currently under multiple stressors that might act in synergy ${ }^{15,16,28,29}$. 
There are two ecotypes of Barents Sea polar bears with distinct space-use strategies, individually stable movement patterns and high site fidelity over years ${ }^{30,31}$. The "pelagic bears" undertake long annual migrations following the ice retreat toward the northeastern part of the Barents Sea, while the "coastal bears" stay on land or on land-fast ice year-round at the western part of the Barents Sea, in the Svalbard Archipelago $0^{30,32}$. The distribution of Barents Sea polar bears has shifted northwards since the beginning of the 1990s due to changes in their habitat and in the abundance and distribution of their main prey ${ }^{14,25,33-36}$. Polar bears depend on sea ice as a platform for hunting and preferentially feed on ringed seals (Pusa hispida), bearded seals (Erignathus barbatus) and harp seals (Phoca groenlandica $)^{37-39}$. However, in the absence of sea ice, Barents Sea polar bears can feed opportunistically on alternative food sources such as ground-nesting bird, seabirds, bird eggs, reindeers, whale carcasses, algae and even vegetation $^{37,39-41}$. The two ecotypes of the Barents Sea are currently facing very different ecological challenges. The migration routes of pelagic bears following the marginal ice zone are getting longer, whereas longer ice-free periods in the Svalbard area force coastal bears to feed on land-based prey.

Previous studies have shown marked differences in pollutants levels between the two ecotypes, with the pelagic polar bears generally having higher pollutant levels than the coastal ones $^{42-44}$. However, the underlying reasons for these differences in pollutant concentrations are largely unknown. Multiple factors can drive these differences including feeding habits, energy expenditure, proximity to emission sources, transport routes and abiotic factors ${ }^{42,44-46}$. Tartu et al. ${ }^{44}$ showed that pelagic females had a higher diet selectivity than the coastal females based on bulk stable isotope ratios of carbon $\left(\delta^{13} \mathrm{C}\right)$ and nitrogen $\left(\delta^{15} \mathrm{~N}\right)$ in red blood cells. However, in order to correctly interpret stable isotope data in predators, the base of the food web (baseline) needs to be constrained. Determining and obtaining baseline stable isotope values can be problematic in animals that forage widely, such as polar bears. Nitrogen stable isotope of amino 
acids $\left(\delta^{15} \mathrm{~N}-\mathrm{AA}\right)$ can overcome this issue, by indirectly fingerprinting the base of the food web, as it conservatively traces $\delta^{15} \mathrm{~N}$ of primary producers. Simultaneously, trophic amino acids (trophic AA), which become enriched during trophic transfer can be used to isolate a predator's trophic position ${ }^{47,48}$. In addition, pelagic bears occupy a wider home range $e^{30,42,44,49}$, and it has been proposed that this results in greater energetic costs, greater prey intake and therefore, higher pollutant levels ${ }^{42}$. Finally, higher levels of pollutants in the pelagic bears, which utilize the northeastern part of the Barents Sea to a greater extent, could be due to a spatial gradient in pollutant concentrations related to proximity of emission sources, uptake and/ or transport routes of pollutants ${ }^{44-46}$.

In the present study, we investigated a suite of ecological drivers in order to decipher drivers of pollutant levels between the two ecotypes of Barents Sea polar bears. Specifically, the foraging habitat and diet were studied with bulk stable isotope ratios of carbon $\left(\delta^{13} \mathrm{C}\right)$ and nitrogen $\left(\delta^{15} \mathrm{~N}\right)$, as proxies of feeding habits. We also used $\delta^{15} \mathrm{~N}-\mathrm{AA}$ as a trophic indication and in order to estimate the polar bear trophic level. Using satellite telemetry data, we studied energy expenditure by estimating field metabolic rate (FMR). Annual home range (HR) size was also determined and potential spatial gradients in pollutants were explored using latitude and longitude centroid positions of polar bears. Finally, pollutant levels were measured in adult harp seals from the Greenland Sea stock and White Sea - Barents Sea stock as a proxy for a WestEast gradient of pollutants in polar bear prey.

\section{Material and methods}
a) Fieldwork 
Adult female polar bears $(n=40 ; 15$ pelagic and 25 coastal $)$ from the Barents Sea were captured throughout the Svalbard Archipelago in spring (29 ${ }^{\text {th }}$ March $-24^{\text {th }}$ April) between 2011 and 2018 (Table S1). One female was captured twice, in 2016 and 2017, whilst the others were captured only once. Immobilization, sampling and handling procedures followed standard protocols $^{50,51}$, and are, together with methods for determination of body condition, age and reproductive status, further described in the supporting information (SI). As concentrations of pollutants are related to body condition and reproductive status ${ }^{24}$, we selected individuals with similar body condition (Table 1) and reproductive status (Table S1) for both ecotypes to avoid confounding effects of these factors ${ }^{44}$.

Blood and adipose tissue samples of adult harp seals of the Greenland Sea stock were collected in April $2017(\mathrm{n}=3)$ and March $2018(\mathrm{n}=7)$ in the pack ice of the Greenland Sea (geographical range: $\mathrm{N} 69^{\circ} 10^{\prime}-72^{\circ} 30, \mathrm{~W} 16^{\circ}-20^{\circ}$ ). Blood and adipose tissue samples of harp seals from the White Sea - Barents Sea stock were collected in April $2018(n=11)$ in the Pechora Sea (geographical position: N69 $52^{\prime}$, W50 $36^{\prime}$ ). Procedures for sampling and estimation of body condition are described in the SI.

b) Determination of ecotype, home range and field metabolic rate

Annual HR size defined as the 50\% minimum convex polygon (MCP) and the location of its centroid were calculated for each bear (detailed in the SI). We assigned each bear to an ecotype ("pelagic" or "coastal"), based on the percentage of overlap between MCP of each individual and the Svalbard area. The Svalbard area was defined as the 4 largest islands in the Svalbard archipelago (Spitsbergen, Nordaustlandet, Edgeøya and Barentsøya) and a $20 \mathrm{~km}$ buffer around each island (Figure 1). A bear was deemed "coastal" if at least half of its 50\% yearly HR was included within the polygon $(n=25$; Figure 1$)$. By contrast, if at least $50 \%$ of 
the bear's HR was outside of this polygon, the bear was deemed "pelagic" ( $\mathrm{n}=15$; Figure 1). Ecotype attribution was checked and validated after visual inspection of each track. The daily speed of each bear was corrected for sea ice drift following the approach taken by Durner et al. ${ }^{52}$ (detailed in the SI). FMR was calculated for each bear based on average daily speed corrected for sea ice drift (as detailed in Blanchet et al. submitted) and following the relationship in Pagano et al. ${ }^{53}$ : Daily FMR $=167.3 *$ speed +153 , where daily FMR is in $\mathrm{KJ} \cdot \mathrm{kg}^{-1} \cdot \mathrm{day}^{-1}$ and speed in $\mathrm{km} \cdot \mathrm{h}^{-1}$. Because denning events and their duration vary substantially between individuals and years, we only investigated FMR in the period between May $\left(1^{\text {st }}\right)$ and September $\left(30^{\text {th }}\right)$, when polar bears do not den.

\section{c) Pollutant measurements}

\section{Organochlorine compounds (OCPs and PCBs) and PBDEs were analyzed from polar bear} $(n=38)$ and harp seal $(n=20)$ adipose tissue. PFASs were analyzed in polar bear plasma $(n=$ 40) and harp seal plasma/serum $(n=20)$. All analyses were conducted at the Norwegian Institute for Air Research (NILU) in Tromsø, Norway, following Scotter et al. ${ }^{54}$ and Hansen et al. ${ }^{55}$. Analytical procedures and quality assurance are given in the SI. We quantified OCPs (trans-, cis-chlordane, oxy-chlordane, trans-, cis-nonachlor, $\alpha-, \beta$-, $\gamma$-hexachlorocyclohexane $[\mathrm{HCH}]$, mirex, hexachlorobenzene [HCB], o, p'- dichlorodiphenyltrichloroethane [DDT], $p, p^{\prime}-$ DDT, $\quad$, $p^{\prime}$-dichlororodiphenyldichloroethane $\quad$ [DDD], $\quad p, p^{\prime}$-DDD, $\quad o, p^{\prime}-$ dichlorodiphenyldichloroethylene [DDE] and $p, p^{\prime}$-DDE), PCBs (-28, -52, -99, -101, -105, -118, $-138,-153,-180,-183,-187,-194)$, PBDEs $(-17,-28,-47,-49,-66,-71,-77,-85,-99,-100,-$ $119,-126,-138,-153,-154,-156,-183,-184,-191,-196,-197,-202,-206,-207,-209)$, perfluoroalkyl sulfonic acids (PFSAs) with 4-10 carbons (C) (both linear and branched $\mathrm{C}_{8}$ ), 4:2, 6:2, 8:2 fluorotelomere sulfonate (FTS), perfluorooctanesulfonamide (FOSA) and $\mathrm{C}_{6-14}$ 
173 perfluoroalkyl carboxylic acids (PFCAs). Only compounds detected in at least $60 \%$ of the

174

175

176

177 samples were used for further statistical analyses and values below the limits of detection (LOD) were replaced by $1 / 2$ LOD. The compounds remaining for further investigation included adipose tissue concentrations of $\sum_{5} \mathrm{CHLs}, \alpha-, \beta$ - $\mathrm{HCH}$ (detected in $\geq 60 \%$ of polar bear samples only), mirex, HCB, p,p'-DDE, ¿PCBs (-99, -105, -118, -138, -153, -180, -183, -187, -194), ¿PBDEs (-47, -99, -100, -153) expressed in ng.g ${ }^{-1}$ lipid weight (lw), and plasma/serum concentrations of $\sum$ PFSAs and $\sum$ PFCAs expressed in ng.g ${ }^{-1}$ wet weight (ww) with following carbon chain lengths: $\mathrm{C}_{5-8}$ PFSAs and $\mathrm{C}_{7-13}$ PFCAs for polar bears, and, $\mathrm{C}_{6-8}$ PFSAs and $\mathrm{C}_{8-13}$ PFCAs for harp seals.

\section{d) Stable isotope analysis (SIA)}

SIA was carried out mostly at the Liverpool Isotope Facility for Environmental Research (LIFER) lab in United Kingdom and partly (26 red blood cell [RBC] samples) at the University of Alaska Anchorage in the USA. The respective role of foraging habitat and diet were investigated in RBCs and hair using bulk SIA ratios of carbon $\left(\delta^{13} \mathrm{C}\right)$ and nitrogen $\left(\delta^{15} \mathrm{~N}\right)^{56}$. Bulk isotopes were used to investigate isotopic niche width as a proxy of the trophic niche ${ }^{57}$. The $\delta^{13} \mathrm{C}$ of a predator reflects the origin of food sources, as there is generally a good discrimination between terrestrial and marine food sources ${ }^{7,58-61}$. The $\delta^{15} \mathrm{~N}$ is commonly used as an indicator of the trophic position of a consumer ${ }^{7,58,59}$, owing to the large trophic fractionation of 2 to 5 per mil (\%o) between each trophic level ${ }^{62}$. We also performed a principal component analysis (PCA) on $\delta^{15} \mathrm{~N}$-trophic AA as a proxy of polar bear trophic position. Finally, polar bear trophic level was estimated from $\delta^{15} \mathrm{~N}-\mathrm{AA}$, using phenylalanine as the "source amino acid" and glutamic acid as the "trophic amino acid" $" 7,63$. This combined approach allowed for robust trophic level estimation, taking account of potential spatial variation of the 
$\delta^{15} \mathrm{~N}$ baseline. Trophic level was computed according to the formula developed by Chikaraishi et al. ${ }^{48,64}$, adapted for marine food webs $^{65}(\beta=2.9 \%$ ), and based on a marine mammal trophic enrichment factor ${ }^{66}\left(\mathrm{TEF}=4.3 \%\right.$; Harbor seal $[$ Phoca vitulina $]: \mathrm{TL}_{\mathrm{Glu} / \mathrm{Phe}}=\left[{ }^{15} \mathrm{~N}_{\mathrm{Glu}}-\delta^{15} \mathrm{~N}_{\mathrm{Phe}}-\right.$ 2.9] / $4.3+1)$. Therefore, $\delta^{13} \mathrm{C}, \delta^{15} \mathrm{~N}, \delta^{15} \mathrm{~N}$-AA are used in the present study as relevant proxies of polar bear feeding habits. RBCs are a metabolically active tissue, having a half-life $\sim 1.5$ months for $\delta^{13} \mathrm{C}$ and at least twice as long for $\delta^{15} \mathrm{~N}$ in polar bears ${ }^{67}$. As a metabolically inert tissue, hair provides information at the time of tissue synthesis, about 6-8 months before sampling in case the bears were sampled in April ${ }^{68}$. Thus, measuring stable isotopes in both RBCs and hair samples can provide a retrospective record of polar bear feeding habits in different seasons over a larger time scale. Sample preparation, instrumental analysis and data processing are further described in detail in the SI.

\section{e) Statistical analysis}

All statistical analyses were performed using R version 3.5.1. In order to compare pollutant concentrations in both ecotypes, we used linear mixed-effect models (LMEs, "nlme" Rpackage, developed by Pinheiro et $\mathrm{al}^{69}$ with $\sum \mathrm{CHLs}$, $\sum \mathrm{PCBs}, \alpha$ - and $\beta$-HCH, mirex, HCB, $p$, $p$ 'DDE, $\sum$ PBDEs, $\sum$ PFSAs and $\sum$ PFCAs as response variables. Pollutants were $\ln$-transformed to meet model assumptions. "Sampling year" was included in each model as a random factor to account for temporal variation of pollutant levels in Barents Sea polar bears ${ }^{70,71}$. As suggested by Zuur et al. ${ }^{72}$, we used the restricted maximum likelihood estimation (REML) method to avoid any potential biased estimations. Similarly, we compared $\delta^{13} \mathrm{C}$ and $\delta^{15} \mathrm{~N}$ signatures (in RBCs and hair), PC1 scores of $\delta^{15} \mathrm{~N}$-trophic AA (in RBCs and hair), estimated trophic level (in RBCs and hair), FMR, HR size, latitude and longitude centroids, and BCI in pelagic $v s$ coastal polar bears. The PC1 scores of $\delta^{15} \mathrm{~N}$-trophic AA were extracted from a PCA performed on 5 
trophic AA inferred from RBCs (alanine, valine, leucine, aspartic acid, glutamic acid) and 4 trophic AA from hair (alanine, proline, aspartic acid, glutamic acid). Prior to PCA, we subtracted the $\delta^{15} \mathrm{~N}$ of phenylalanine from the $\delta^{15} \mathrm{~N}$ of each trophic AA to remove potential bias due to variation in the baseline, and scaled the baseline corrected $\delta^{15} \mathrm{~N}$ values of each trophic AA using a z-transformation. Higher PC1 scores indicate increasing trophic positions of polar bears. Isotopic niche widths (inferred from $\delta^{13} \mathrm{C}$ and $\delta^{15} \mathrm{~N}$ in RBCs and hair) of both ecotypes were illustrated by standard ellipses (containing 95\% of the data) on an isotopic biplot (Figure 2 \& S1) using "SIBER" R-package ${ }^{73}$. The areas of the resultant ellipses were then computed using both the maximum likelihood (SEAc, adjusted for small sample size) and the Bayesian approaches (SEAb; parameterized as detailed in Jackson et al. ${ }^{73}$ ) (Figure 2 \& S1). Estimated SEA values were directly compared in a probabilistic manner in terms of similarity between pelagic and coastal bears ${ }^{73}$. Pollutant levels and body condition between the Greenland Sea and White Sea - Barents Sea harp seals were compared with linear models.

To investigate the influence of the ecological drivers on pollutant concentrations in Barents Sea polar bears, we tested and quantified the effects of feeding habits $\left(\delta^{13} \mathrm{C}, \delta^{15} \mathrm{~N}\right.$ and estimated trophic level from $\left.\delta^{15} \mathrm{~N}-\mathrm{AA}\right)$, energetic cost (FMR), spatial gradient in pollutants (latitude and longitude centroid positions) and BCI on pollutant concentrations, regardless of which ecotype they belonged to. We used LMEs with ln-transformed $\sum$ CHLs, $\sum$ PCBs, $\alpha$ - and $\beta$-HCH, mirex, HCB, $p, p^{\prime}$-DDE, $\sum$ PBDEs, $\sum$ PFSAs and $\sum$ PFCAs as response variables; and $\delta^{13} \mathrm{C}$ (both RBCs and hair), $\delta^{15} \mathrm{~N}$ (both RBCs and hair), trophic level (both RBCs and hair), FMR, latitude and longitude centroids, and BCI as predictors. "Sampling year" was included in each model as a random factor. All predictors were standardized (scaled to mean $=0$ and standard deviation $=$ 1) to facilitate the comparison of their effect $\operatorname{size}^{74}$. We generated a model set containing ecologically relevant sub-models from the set of predictors of interest and including an intercept model (null model). Significantly correlated predictor variables were not included within the 
same model to minimize any collinearity concerns ${ }^{75}$ (Table S2). This resulted in a final set of 44 competitive models (Table S3). Models (parameterized with the maximum likelihood estimation as suggested in Zuur et al. $^{72}$ ) were first ranked using an information-theoretic approach based on the Akaike's information criterion corrected for small sample size (AICc) ${ }^{76}$. The AIC weight $\left(w_{i}\right)$ was estimated and can be interpreted as the probability that the model $i$ is the best fit, given the candidate set of models ${ }^{77}$. We then performed conditional model averaging (parameterized with the REML estimation as suggested by Zuur et al. ${ }^{72}$ ) from the selected models (cut-off value $\left.=\operatorname{cum}\left[\sum w_{i} \leq 0.95\right]\right)$ as described in Grueber et al. ${ }^{78}$. This method produces averaged estimates of all predictors, weighted according to their $w_{i}{ }^{76,79}$. For all the predictor variables considered in the selected models, we finally determined conditional parameter-averaged estimates and 95\% confidence intervals (CI). CIs provide information about the range in which the true estimate value lies with a certain degree of probability, as well as the strength and direction of the demonstrated effect ${ }^{80}$. As a general guideline, if CIs do not cross zero, it can be assumed that the predictor significantly affects the response variable. Diagnostic plots were assessed on residuals to test whether the data met the assumptions of LMEs.

\section{Results and discussion}

a) Pollutant levels: pelagic vs coastal polar bears

Pelagic polar bears generally had higher levels of pollutants than coastal bears (Table $1 \&$ S4). Median concentrations of $\sum$ CHLs, $\beta$-HCH, $p, p$ '-DDE, $\sum$ PFSAs and $\sum$ PFCAs were $64 \%$, $39 \%, 117 \%, 49 \%$ and $52 \%$ higher in pelagic bears than in coastal bears (Table 1$)$. With the exception of $\alpha-\mathrm{HCH}$, all other compounds investigated, were higher in the pelagic bears, 
273 although these differences were not significant (Table 1). Previous studies have already

\section{b) Polar bear trophic position}

The trophic level estimates based on $\delta^{15} \mathrm{~N}$ values of phenylalanine and glutamic acid suggested that the Barents Sea polar bears occupy trophic level $\approx 3$ (i.e. secondary consumer; Table 1), which is lower than expected for an apex predator ${ }^{7,58} . \delta^{15} \mathrm{~N}$-AA have not been investigated in polar bears before, and so a TEF from another marine mammal species was used (i.e. Harbor seal ${ }^{66}$ ), to determine trophic level. However, TEFs have been shown to vary greatly between species $^{81}$, and previous studies reported consistent underestimation of trophic levels inferred from $\delta^{15} \mathrm{~N}-\mathrm{AA}$ across a range of diverse wild marine predators, likely due to the use of inappropriate TEFs ${ }^{65,66,82-86}$. In addition, we assumed that polar bears from this study fed mainly on marine prey, and determined trophic level based on an equation developed for marine food webs. However, coastal polar bears from the Barents Sea also consume terrestrial prey $39,41,87,88$, and the use of an equation developed for terrestrial food webs would have led to higher trophic level estimations ${ }^{64,65}$. According to the formula developed by Chikaraishi et al. ${ }^{64}$ for terrestrial C3 plant food webs, we found an alternative estimates for trophic level $\approx 3.5$ for coastal polar bears (compared to $\approx 2.7$ ). Despite the notable underestimation of polar bear trophic level, we report very high correlations between the estimated trophic level and PC1 scores of $\delta^{15} \mathrm{~N}$-trophic AA (Figure S2), suggesting that the trophic level based on $\delta^{15} \mathrm{~N}$ values of phenylalanine and 
glutamic acid is a reliable trophic indicator in the present study. However, further studies are needed to define appropriate TEF and $\beta$ values for polar bears.

\section{c) The role of feeding habits}

The trophic level estimates based on $\delta^{15} \mathrm{~N}$ values of phenylalanine and glutamic acid tended to be higher in the pelagic bears, but the differences were less than one trophic level (Table 1). There were no significant differences in the $\delta^{15} \mathrm{~N}$-trophic AA scores of PC1 scores between bears from each ecotype (Figure S3, LMEs; $p=0.142$ for RBCs and $p=0.190$ for hair), suggesting that coastal and pelagic polar bears maintain similar trophic levels. However, $\delta^{13} \mathrm{C}$ and isotopic niche width differed significantly between the two ecotypes (Table 1; Figure 2, S1 \& S3; probability $=1$ for hair and $\mathrm{RBCs}$ ). The higher $\delta^{13} \mathrm{C}$ values and the restricted isotopic niche of pelagic polar bears suggests a selective diet essentially or exclusively composed of marine prey (i.e. seals), whereas the lower $\delta^{13} \mathrm{C}$ values and the wider isotopic niche of coastal polar bears suggests a mixed diet including marine and terrestrial prey. Presence of terrestrial prey in polar bears diet from Svalbard has also been shown by earlier studies ${ }^{39,41,87,88}$. In addition, model-averaged estimates indicated that trophic levels and diet composition determined from $\delta^{15} \mathrm{~N}-\mathrm{AA}, \delta^{15} \mathrm{~N}$ and $\delta^{13} \mathrm{C}$ signatures were important predictors of pollutant levels in Barents Sea polar bears (Figure 3). Concentrations of $\sum$ CHLs, $\sum$ PCBs, $\beta$-HCH, mirex, $\sum$ PBDEs and $\sum$ PFCAs increased significantly with $\delta^{15} \mathrm{~N}$ in RBCs. Similarly, concentrations of $\beta$-HCH increased significantly and $\sum$ CHLs tended to increase with $\delta^{15} \mathrm{~N}$ in hair (Figure 3). We also found positive trends between trophic levels inferred from $\delta^{15} \mathrm{~N}-\mathrm{AA}$ in hair and $\sum \mathrm{CHLs}$ and $p, p^{\prime}-\mathrm{DDE}$, whereas $\sum$ PBDEs increased with trophic level in RBCs (Figure 3). Finally, concentrations of $\sum$ CHLs, $\beta$-HCH, $\sum$ PBDEs, $\sum$ PFSAs, $\sum$ PFCAs increased significantly with $\delta^{13} \mathrm{C}$ in hair and/or RBCs, whereas concentrations of $\sum \mathrm{PCBs}$ and mirex tended to increase with 
$323 \delta^{13} \mathrm{C}$ in hair and/or RBCs (Figure 3). For example, median concentrations of $\sum$ CHLs were about

3243.5 times higher in bears with a predominantly marine diet at the highest trophic level compared

325 to the bears with a mixed diet at the lowest trophic level. Our results are in agreement with 326 previous findings, which indicated that bears with a predominantly marine diet and higher 327 trophic level accumulated higher concentrations of pollutants than bears at a lower trophic level, 328 which fed on a mixed diet including terrestrial prey ${ }^{20,24,44,70}$.

d) The role of energy expenditure

FMR reflects energy expenditure of polar bears during both resting and active time such as feeding and movements. FMR in pelagic polar bears was 29\% higher than FMR in coastal individuals (Table 1). This is consistent with the use of larger areas as shown by the size of their HR, which were $200 \%$ larger compared to HR occupied by coastal individuals (Table 1 ). Pelagic polar bears have greater energy expenditure (detailed in Blanchet et al. submitted), presumably because they spend more time in motion in order to reach their foraging habitat and because they hunt for seals over larger areas, than coastal bears, which live in more confined areas, feeding opportunistically on an alternative locally distributed diet (e.g. coastal ringed seal, whale carcass, seabird colonies, algae). Consequently, pelagic polar bears have higher energy requirements and thus, higher food consumption. In addition, model-averaged estimates indicated that $\sum$ CHLs concentrations were 2 times higher in bears with the highest FMR compared to those with the lowest FMR (Figure 3). Similar, but less pronounced and nonsignificant tendencies were found for $\Sigma$ PCBs, HCB and $\sum$ PFCAs (Figure 3). This supports the previous assumption made by Olsen et al. ${ }^{42}$ suggesting that polar bears with larger HR have greater energetic costs, greater food intake and consequently, higher pollutant assimilation. 
e) The ice edge effect

Pelagic polar bears were distributed further north compared to coastal polar bears (Figure

351

352

353

354

355

356

357

358

359

360

361

362

1; Table 1). Moreover, model-averaged estimates indicated significantly increasing concentrations of $\sum$ CHLs, $\sum$ PCBs, mirex, $p, p$ '-DDE and $\sum$ PBDEs with latitude centroid, being 2.5 to 5.2 times higher in the northernmost compared to the southernmost bears (Figure 3 ). Higher pollutant levels in polar bears using higher latitudes, in line with recent findings ${ }^{43,44}$, are likely related to the location of the sea ice edge, which is for the most of the year north of Svalbard. Indeed, it has been proposed that when sea ice melts and retreats during spring and summer, pollutants deposited on snow and stocked in ice are released in large quantities into the water column and subsequently bioaccumulate within the lipid-rich and low ice-associated food web ${ }^{89,90}$. Once assimilated, POPs biomagnify in upper trophic consumers until reaching elevated concentrations in seals, which are then eaten by polar bears in spring and early summer ${ }^{91}$. Interestingly, concentrations of PCBs have been shown to be negatively related to latitude in Barents Sea polar bears monitored in the 1990s, which has also been related to the location of the sea ice edge ${ }^{42}$. However, the marginal sea ice zone was located much further south in the Barents Sea in 1990s than during our study period ${ }^{92-94}$.

\section{f) The existence of a West-East pollutant gradient}

\section{Pelagic polar bears were distributed further east compared to coastal polar bears (Figure 1;} Table 1). Model-averaged estimates indicated significant increasing concentrations of $p, p^{\prime}-$ DDE, $\sum$ PFSAs and $\sum$ PFCAs with longitude centroid, being 6.3, 3.2 and 2.8 times higher in the easternmost compared to the westernmost bears (Figure 3). Similar trends were found for $\Sigma \mathrm{CHLs}$ and $\beta$-HCH (Figure 3). Accordingly, harp seals from the White Sea - Barents Sea stock 
373 had generally higher levels of pollutants than those from Greenland Sea stock (Table 2 \& S4).

374 Median concentrations of $\sum$ CHLs, $\sum$ PCBs, HCB, $p, p$ '-DDE and $\sum$ PFSAs were 53\%, 82\%, $37562 \%, 70 \%$ and $88 \%$ higher in White Sea - Barents Sea harp seals than in those from the Greenland Sea (Table 2). Our results, in line with recent findings ${ }^{43-46}$, indicate higher 377 contaminant levels in the eastern part of the Barents Sea compared to more western areas. This suggests the existence of a pollutant gradient with increasing trends from Svalbard archipelago to western Russia. Such geographical pattern of pollutant levels could be related to proximity to pollutant emission sources and transport pathways. Discharges of lipophilic POPs from large rivers outflows in the western Russian Arctic have been suggested as an important source of pollutants in this area ${ }^{6,95}$. Emissions of volatile PFAS precursors from the Russian and Chinese industry or elsewhere ${ }^{96,97}$, can be transported to the eastern part of the Barents Sea through atmospheric currents and subsequently deposited on sea ice ${ }^{98}$. Due to a dilution effect, PFASs are generally more concentrated in surface snow than in seawater ${ }^{99,100}$. During melting periods, a considerable amount of pollutants are released, assimilated and biomagnified within polar food webs, ultimately terminating in polar bears.

g) Implications

Our results indicate that pelagic polar bears from the Barents Sea are exposed to higher levels of pollutants than their coastal counterparts because (1) they feed on higher proportion of marine and high-trophic level prey, (2) they have higher energy requirements and subsequently higher prey consumption, (3) they forage in the marginal ice zones, and (4) they feed on prey located closer to pollutant emission sources/ transport pathways. In this study, we selected pelagic and coastal polar bears with similar body condition to avoid confounding effects for our analyses. Larger studies based on random sampling on bears indicated that 
pelagic females are fatter than coastal females ${ }^{44}$ (e.g. Blanchet et al. submitted), and only concentrations of proteinophilic PFASs were reported to be higher in pelagic females ${ }^{44}$. Tartu et al. ${ }^{44}$ concluded that the lack of difference in plasma concentrations of lipophilic POPs between coastal and pelagic polar bears was likely masked by difference in body condition. Future studies should aim to predict how rapidly declining sea ice in the Barents $\mathrm{Sea}^{27}$, which is likely to challenge polar bears energetically ${ }^{101}$, will influence contaminant fate and exposure in Barents Sea polar bears.

\section{Acknowledgments}

The study was financed by the Norwegian Ministry of Climate and Environment (RUS16/0003) and the Norwegian Polar Institute. The polar bear fieldwork was supported by World Wildlife Fund. We thank Conrad Helgeland for data base management; Martin Kristiansen and Nils Erik Skavberg for harp seal sampling; Jade Vacquie-Garcia and Sabrina Tartu for statistical advice; and the two anonymous referees for their comments. Merete Miøen, Arntraut Götsch and Mikael Harju contributed in the analyses of the samples for pollutants in the NILU lab; and Jeffrey Welker and Annalis Brownlee, University of Alaska Anchorage, in mass spectrometry analyses of RBCs samples for bulk stable isotopes. Sampling of harp seals from the Greenland stock was supported by the National Fund for Scientific Research (F.R.S.-FNRS). 
(1) Wania, F.; Mackay, D. Global Fractionation and Cold Condensation of Low Volatility Organochlorine Compounds in Polar Regions. Ambio 1993, 22, 10-18.

(2) Wania, F.; Mackay, D. Peer Reviewed: Tracking the Distribution of Persistent Organic Pollutants. Environ. Sci. Technol. 1996, 30 (9), 390A-396A.

(3) Ellis, D. A.; Martin, J. W.; De Silva, A. O.; Mabury, S. A.; Hurley, M. D.; Sulbaek Andersen, M. P.; Wallington, T. J. Degradation of Fluorotelomer Alcohols: A Likely Atmospheric Source of Perfluorinated Carboxylic Acids. Environ. Sci. Technol. 2004, 38 (12), 3316-3321.

(4) Wania, F. A Global Mass Balance Analysis of the Source of Perfluorocarboxylic Acids in the Arctic Ocean. Environ. Sci. Technol. 2007, 41 (13), 4529-4535.

(5) Taniyasu, S.; Yamashita, N.; Moon, H.-B.; Kwok, K. Y.; Lam, P. K.; Horii, Y.; Petrick, G.; Kannan, K. Does Wet Precipitation Represent Local and Regional Atmospheric Transportation by Perfluorinated Alkyl Substances? Environ. Int. 2013, 55, 25-32.

(6) Sobek, A.; Gustafsson, Ö. Deep Water Masses and Sediments Are Main Compartments for Polychlorinated Biphenyls in the Arctic Ocean. Environ. Sci. Technol. 2014, 48 (12), 6719-6725.

(7) Hobson, K. A.; Fisk, A.; Karnovsky, N.; Holst, M.; Gagnon, J.-M.; Fortier, M. A Stable Isotope $\left(\delta^{13} \mathrm{C}, \delta^{15} \mathrm{~N}\right)$ Model for the North Water Food Web: Implications for Evaluating Trophodynamics and the Flow of Energy and Contaminants. Deep Sea Res. Part II Top. Stud. Oceanogr. 2002, 49 (22-23), 5131-5150.

(8) Sørmo, E. G.; Salmer, M. P.; Jenssen, B. M.; Hop, H.; Bæk, K.; Kovacs, K. M.; Lydersen, C.; Falk-Petersen, S.; Gabrielsen, G. W.; Lie, E. Biomagnification of Polybrominated Diphenyl Ether and Hexabromocyclododecane Flame Retardants in the Polar Bear Food Chain in Svalbard, Norway. Environ. Toxicol. Chem. Int. J. 2006, 25 (9), 2502-2511.

(9) Kelly, B. C.; Ikonomou, M. G.; Blair, J. D.; Morin, A. E.; Gobas, F. A. Food WebSpecific Biomagnification of Persistent Organic Pollutants. Science 2007, 317 (5835), 236-239.

(10) Kelly, B. C.; Ikonomou, M. G.; Blair, J. D.; Surridge, B.; Hoover, D.; Grace, R.; Gobas, F. A. Perfluoroalkyl Contaminants in an Arctic Marine Food Web: Trophic Magnification and Wildlife Exposure. Environ. Sci. Technol. 2009, 43 (11), 4037-4043.

(11) Letcher, R. J.; Gebbink, W. A.; Sonne, C.; Born, E. W.; McKinney, M. A.; Dietz, R. Bioaccumulation and Biotransformation of Brominated and Chlorinated Contaminants and Their Metabolites in Ringed Seals (Pusa Hispida) and Polar Bears (Ursus Maritimus) from East Greenland. Environ. Int. 2009, 35 (8), 1118-1124.

(12) Stroeve, J.; Notz, D. Changing State of Arctic Sea Ice across All Seasons. Environ. Res. Lett. 2018, 13 (10), 103001.

(13) Laidre, K. L.; Stirling, I.; Lowry, L. F.; Wiig, Ø.; Heide-Jørgensen, M. P.; Ferguson, S. H. Quantifying the Sensitivity of Arctic Marine Mammals to Climate-induced Habitat Change. Ecol. Appl. 2008, 18 (sp2), S97-S125.

(14) Stirling, I.; Derocher, A. E. Effects of Climate Warming on Polar Bears: A Review of the Evidence. Glob. Change Biol. 2012, 18 (9), 2694-2706.

(15) Jenssen, B. M.; Villanger, G. D.; Gabrielsen, K. M.; Bytingsvik, J.; Bechshoft, T.; Ciesielski, T. M.; Sonne, C.; Dietz, R. Anthropogenic Flank Attack on Polar Bears: Interacting Consequences of Climate Warming and Pollutant Exposure. Front. Ecol. Evol. 2015, 3, 16.

(16) Andersen, M.; Aars, J. Barents Sea Polar Bears (Ursus Maritimus): Population Biology and Anthropogenic Threats. Polar Res. 2016, 35 (1), 26029. 
(17) Jenssen, B. M. Endocrine-Disrupting Chemicals and Climate Change: A Worst-Case Combination for Arctic Marine Mammals and Seabirds? Environ. Health Perspect. 2005, 114, 76-80.

(18) McKinney, M. A.; Letcher, R. J.; Aars, J.; Born, E. W.; Branigan, M.; Dietz, R.; Evans, T. J.; Gabrielsen, G. W.; Peacock, E.; Sonne, C. Flame Retardants and Legacy Contaminants in Polar Bears from Alaska, Canada, East Greenland and Svalbard, 20052008. Environ. Int. 2011, 37 (2), 365-374.

(19) Routti, H.; Atwood, T. C.; Bechshoft, T.; Boltunov, A.; Ciesielski, T. M.; Desforges, J.P.; Dietz, R.; Gabrielsen, G. W.; Jenssen, B. M.; Letcher, R. J.; McKinney, M.; Morris, A. D.; Rigét, F. F.; Sonne, C.; Styrishave, B.; Tartu, S. State of Knowledge on Current Exposure, Fate and Potential Health Effects of Contaminants in Polar Bears from the Circumpolar Arctic. Sci. Total Environ. 2019, 664, 1063-1083. https://doi.org/10.1016/j.scitotenv.2019.02.030.

(20) Tartu, S.; Bourgeon, S.; Aars, J.; Andersen, M.; Lone, K.; Jenssen, B. M.; Polder, A.; Thiemann, G. W.; Torget, V.; Welker, J. M.; Routti, H. Diet and Metabolic State Are the Main Factors Determining Concentrations of Perfluoroalkyl Substances in Female Polar Bears from Svalbard. Environ. Pollut. 2017, 229, 146-158. https://doi.org/10.1016/j.envpol.2017.04.100.

(21) Kissa, E. Fluorinated Surfactants and Repellents, 2 ${ }^{\text {nd }}$, ed.; Marcel Dekker: New York, 2001.

(22) Buck, R. C.; Franklin, J.; Berger, U.; Conder, J. M.; Cousins, I. T.; de Voogt, P.; Jensen, A. A.; Kannan, K.; Mabury, S. A.; van Leeuwen, S. P. Perfluoroalkyl and Polyfluoroalkyl Substances in the Environment: Terminology, Classification, and Origins. Integr. Environ. Assess. Manag. 2011, 7 (4), 513-541. https://doi.org/10.1002/ieam.258.

(23) Buck, R. C.; Murphy, P. M.; Pabon, M. Chemistry, Properties, and Uses of Commercial Fluorinated Surfactants. In Polyfluorinated Chemicals and Transformation Products; Knepper, T. P., Lange, F. T., Eds.; The Handbook of Environmental Chemistry; Springer Berlin Heidelberg: Berlin, Heidelberg, 2012; pp 1-24. https://doi.org/10.1007/978-3642-21872-9_1.

(24) Tartu, S.; Bourgeon, S.; Aars, J.; Andersen, M.; Polder, A.; Thiemann, G. W.; Welker, J. M.; Routti, H. Sea Ice-Associated Decline in Body Condition Leads to Increased Concentrations of Lipophilic Pollutants in Polar Bears (Ursus Maritimus) from Svalbard, Norway. Sci. Total Environ. 2017, 576, 409-419. https://doi.org/10.1016/j.scitotenv.2016.10.132.

(25) Stirling, I.; Derocher, A. E. Possible Impacts of Climatic Warming on Polar Bears. Arctic 1993, 46 (3), 240-245.

(26) Amstrup, S. C.; DeMaster, D. P. Polar bear, Ursus maritimus. In Wild mammals of North America: biology, management, and conservation; Feldhamer, G. A.; Thompson, B. S. C. 2003, 2, 587-610.

(27) Stern, H. L.; Laidre, K. L. Sea-Ice Indicators of Polar Bear Habitat. The Cryosphere 2016, 10 (5), 2027-2041. https://doi.org/10.5194/tc-10-2027-2016.

(28) McKinney, M. A. A Review of Ecological Impacts of Global Climate Change on Persistent Organic Pollutant and Mercury Pathways and Exposures in Arctic Marine Ecosystems. Curr. Zool. 2015, 61 (4), 617-628.

(29) Routti, H.; Jenssen, B. M.; Tartu, S. Chapter 13 - Ecotoxicologic Stress in Arctic Marine Mammals, With Particular Focus on Polar Bears. In Marine Mammal Ecotoxicology; Fossi, M. C., Panti, C., Eds.; Academic Press, 2018; pp 345-380. https://doi.org/10.1016/B978-0-12-812144-3.00013-9. 
(30) Mauritzen, M.; Derocher, A. E.; Wiig, Ø. Space-Use Strategies of Female Polar Bears in a Dynamic Sea Ice Habitat. Can. J. Zool. 2001, 79 (9), 1704-1713. https://doi.org/10.1139/z01-126.

(31) Lone, K.; Aars, J.; \& Ims, R. A. Site fidelity of Svalbard polar bears revealed by markrecapture positions. Polar biology 2013, 36 (1), 27-39.

(32) Mauritzen, M.; Belikov, S. E.; Boltunov, A. N.; Derocher, A. E.; Hansen, E.; Ims, R. A.; Wiig, Ø.; Yoccoz, N. Functional Responses in Polar Bear Habitat Selection. Oikos 2003, 100 (1), 112-124. https://doi.org/10.1034/j.1600-0706.2003.12056.x.

(33) Thiemann, G. W.; Iverson, S. J.; Stirling, I. Polar Bear Diets and Arctic Marine Food Webs: Insights from Fatty Acid Analysis. Ecol. Monogr. 2008, 78 (4), 591-613. https://doi.org/10.1890/07-1050.1.

(34) McKinney, M. A.; Peacock, E.; Letcher, R. J. Sea Ice-Associated Diet Change Increases the Levels of Chlorinated and Brominated Contaminants in Polar Bears. Environ. Sci. Technol. 2009, 43 (12), 4334-4339. https://doi.org/10.1021/es900471g.

(35) McKinney, M. A.; Iverson, S. J.; Fisk, A. T.; Sonne, C.; Rigét, F. F.; Letcher, R. J.; Arts, M. T.; Born, E. W.; Rosing-Asvid, A.; Dietz, R. Global Change Effects on the LongTerm Feeding Ecology and Contaminant Exposures of East Greenland Polar Bears. Glob. Change Biol. 2013, 19 (8), 2360-2372. https://doi.org/10.1111/gcb.12241.

(36) Lone, K.; Merkel, B.; Lydersen, C.; Kovacs, K. M.; Aars, J. Sea Ice Resource Selection Models for Polar Bears in the Barents Sea Subpopulation. Ecography 2018, 41 (4), 567578. https://doi.org/10.1111/ecog.03020.

(37) Løno, O. The Polar Bear (Ursus Maritimus) in the Svalbard Area, Norsk Polarinstitutt Skrifter. 1970, 149.

(38) Derocher, A. E.; Wiig, Ø.; Andersen, M. Diet Composition of Polar Bears in Svalbard and the Western Barents Sea. Polar Biol. 2002, 25 (6), 448-452. https://doi.org/10.1007/s00300-002-0364-0.

(39) Iversen, M.; Aars, J.; Haug, T.; Alsos, I. G.; Lydersen, C.; Bachmann, L.; Kovacs, K. M. The Diet of Polar Bears (Ursus Maritimus) from Svalbard, Norway, Inferred from Scat Analysis. Polar Biol. 2013, 36 (4), 561-571. https://doi.org/10.1007/s00300-012-12842.

(40) Prop, J.; Aars, J.; Bårdsen, B.-J.; Hanssen, S. A.; Bech, C.; Bourgeon, S.; de Fouw, J.; Gabrielsen, G. W.; Lang, J.; Noreen, E.; Oudman, T.; Sittler, B.; Stempniewicz, L.; Tombre, I.; Wolters, E.; Moe B. Climate Change and the Increasing Impact of Polar Bears on Bird Populations. Front. Ecol. Evol. 2015, 3, 33. https://doi.org/10.3389/fevo.2015.00033.

(41) Tartu, S.; Bourgeon, S.; Aars, J.; Andersen, M.; Ehrich, D.; Thiemann, G. W.; Welker, J. M.; Routti, H. Geographical Area and Life History Traits Influence Diet in an Arctic Marine Predator. PLOS ONE 2016, $11 \quad$ (5), 0155980. https://doi.org/10.1371/journal.pone.0155980.

(42) Olsen, G. H.; Mauritzen, M.; Derocher, A. E.; Sørmo, E. G.; Skaare, J. U.; Wiig, Ø.; Jenssen, B. M. Space-Use Strategy Is an Important Determinant of PCB Concentrations in Female Polar Bears in the Barents Sea. Environ. Sci. Technol. 2003, 37 (21), 49194924. https://doi.org/10.1021/es034380a.

(43) van Beest, F. M.; Aars, J.; Routti, H.; Lie, E.; Andersen, M.; Pavlova, V.; Sonne, C.; Nabe-Nielsen, J.; Dietz, R. Spatiotemporal Variation in Home Range Size of Female Polar Bears and Correlations with Individual Contaminant Load. Polar Biol. 2016, 39 (8), 1479-1489. https://doi.org/10.1007/s00300-015-1876-8.

(44) Tartu, S.; Aars, J.; Andersen, M.; Polder, A.; Bourgeon, S.; Merkel, B.; Lowther, A. D.; Bytingsvik, J.; Welker, J. M.; Derocher, A. E.; Jenssen, B. M; Routti, H. Choose Your Poison-Space-Use Strategy Influences Pollutant Exposure in Barents Sea Polar Bears. 

Environ.
Sci.
Technol.
2018 , 52
(5),
3211-3221.

https://doi.org/10.1021/acs.est.7b06137.

(45) Andersen, M.; Lie, E.; Derocher, A. E.; Belikov, S. E.; Bernhoft, A.; Boltunov, A. N.; Garner, G. W.; Skaare, J. U.; Wiig, Ø. Geographic Variation of PCB Congeners in Polar Bears (Ursus Maritimus) from Svalbard East to the Chukchi Sea. Polar Biol. 2001, 24 (4), 231-238. https://doi.org/10.1007/s003000000201.

(46) Lie, E.; Bernhoft, A.; Riget, F.; Belikov, S. E.; Boltunov, A. N.; Derocher, A. E.; Garner, G. W.; Wiig, Ø.; Skaare, J. U. Geographical Distribution of Organochlorine Pesticides (OCPs) in Polar Bears (Ursus Maritimus) in the Norwegian and Russian Arctic. Sci. Total Environ. 2003, 306 (1), 159-170. https://doi.org/10.1016/S0048-9697(02)00490-4.

(47) McClelland, J. W.; Montoya, J. P. Trophic Relationships and the Nitrogen Isotopic Composition of Amino Acids in Plankton. Ecology 2002, 83 (8), 2173-2180. https://doi.org/10.1890/0012-9658(2002)083[2173:TRATNI]2.0.CO;2.

(48) Chikaraishi, Y.; Ogawa, N. O.; Kashiyama, Y.; Takano, Y.; Suga, H.; Tomitani, A.; Miyashita, H.; Kitazato, H.; Ohkouchi, N. Determination of Aquatic Food-Web Structure Based on Compound-Specific Nitrogen Isotopic Composition of Amino Acids. Limnol. Oceanogr. Methods 2009, 7 (11), 740-750. https://doi.org/10.4319/lom.2009.7.740.

(49) Mauritzen, M.; Derocher, A. E.; Wiig, Ø.; Belikov, S. E.; Boltunov, A. N.; Hansen, E.; Garner, G. W. Using Satellite Telemetry to Define Spatial Population Structure in Polar Bears in the Norwegian and Western Russian Arctic. J. Appl. Ecol. 2002, 39 (1), 79-90. https://doi.org/10.1046/j.1365-2664.2002.00690.x.

(50) Stirling, I.; Spencer, C.; Andriashek, D. Immobilization of Polar Bears (Ursus Maritimus) with Telazol® in the Canadian Arctic. J. Wildl. Dis. 1989, 25 (2), 159-168. https://doi.org/10.7589/0090-3558-25.2.159.

(51) Derocher, A. E.; Wiig, Ø. Postnatal Growth in Body Length and Mass of Polar Bears (Ursus Maritimus) at Svalbard. J. Zool. 2002, $256 \quad$ (3), 343-349. https://doi.org/10.1017/S0952836902000377.

(52) Durner, G. M.; Douglas, D. C.; Albeke, S. E.; Whiteman, J. P.; Amstrup, S. C.; Richardson, E.; Wilson, R. R.; Ben-David, M. Increased Arctic Sea Ice Drift Alters Adult Female Polar Bear Movements and Energetics. Glob. Change Biol. 2017, 23 (9), 34603473.

(53) Pagano, A. M.; Durner, G. M.; Rode, K. D.; Atwood, T. C.; Atkinson, S. N.; Peacock, E.; Costa, D. P.; Owen, M. A.; Williams, T. M. High-Energy, High-Fat Lifestyle Challenges an Arctic Apex Predator, the Polar Bear. Science 2018, 359 (6375), 568-572. https://doi.org/10.1126/science.aan8677.

(54) Scotter, S. E.; Tryland, M.; Nymo, I. H.; Hanssen, L.; Harju, M.; Lydersen, C.; Kovacs, K. M.; Klein, J.; Fisk, A. T.; Routti, H. Contaminants in Atlantic Walruses in Svalbard Part 1: Relationships between Exposure, Diet and Pathogen Prevalence. Environ. Pollut. 2019, 244, 9-18. https://doi.org/10.1016/j.envpol.2018.10.001.

(55) Hanssen, L.; Dudarev, A. A.; Huber, S.; Odland, J. Ø.; Nieboer, E.; Sandanger, T. M. Partition of Perfluoroalkyl Substances (PFASs) in Whole Blood and Plasma, Assessed in Maternal and Umbilical Cord Samples from Inhabitants of Arctic Russia and Uzbekistan. Sci. Total Environ. 2013, 447, 430-437. https://doi.org/10.1016/j.scitotenv.2013.01.029.

(56) Newsome, S. D.; Clementz, M. T.; Koch, P. L. Using Stable Isotope Biogeochemistry to Study Marine Mammal Ecology. Mar. Mammal Sci. 2010, 26 (3), 509-572. https://doi.org/10.1111/j.1748-7692.2009.00354.x.

(57) Newsome, S. D.; Rio, C. M. del; Bearhop, S.; Phillips, D. L. A Niche for Isotopic Ecology. Front. Ecol. Environ. 2007, 5 (8), 429-436. https://doi.org/10.1890/060150.1. 
613

614

615

616

617

618

619

620

621

622

623

624

625

626

627

628

629

630

631

632

633

634

635

636

637

638

639

640

641

642

643

644

645

646

647

648

649

650

651

652

653

654

655

656

657

658

659

660

661
(58) Hobson, K. A.; Welch, H. E. Determination of Trophic Relationships within a High Arctic Marine Food Web Using $\delta^{13} \mathrm{C}$ and $\delta^{15} \mathrm{~N}$ Analysis. Mar. Ecol. Prog. Ser. 1992, 84 (1), 9-18.

(59) Kelly, J. F. Stable Isotopes of Carbon and Nitrogen in the Study of Avian and Mammalian Trophic Ecology. Can. J. Zool. 2000, 78 (1), 1-27. https://doi.org/10.1139/z99-165.

(60) Hobson, K. A.; Piatt, J. F.; Pitocchelli, J. Using Stable Isotopes to Determine Seabird Trophic Relationships. J. Anim. Ecol. 1994, 63 (4), 786-798. https://doi.org/10.2307/5256.

(61) Hobson, K. A. Tracing Origins and Migration of Wildlife Using Stable Isotopes: A Review. Oecologia 1999, 120 (3), 314-326. https://doi.org/10.1007/s004420050865.

(62) Minagawa, M.; Wada, E. Stepwise Enrichment of ${ }^{15} \mathrm{~N}$ along Food Chains: Further Evidence and the Relation between $\delta^{15} \mathrm{~N}$ and Animal Age. Geochim. Cosmochim. Acta 1984, 48 (5), 1135-1140. https://doi.org/10.1016/0016-7037(84)90204-7.

(63) Popp, B. N.; Graham, B. S.; Olson, R. J.; Hannides, C. C. S.; Lott, M. J.; López-Ibarra, G. A.; Galván-Magaña, F.; Fry, B. Insight into the Trophic Ecology of Yellowfin Tuna, Thunnus Albacares, from Compound-Specific Nitrogen Isotope Analysis of Proteinaceous Amino Acids. In Terrestrial Ecology; Stable Isotopes as Indicators of Ecological Change; Elsevier, 2007; Vol. 1, pp 173-190. https://doi.org/10.1016/S19367961(07)01012-3.

(64) Chikaraishi, Y.; Ogawa, N. O.; Ohkouchi, N. Further evaluation of the trophic level estimation based on nitrogen isotopic composition of amino acids. In Earth, life, and isotopes; 2010; 37-51.

(65) Nielsen, J. M.; Popp, B. N.; Winder, M. Meta-Analysis of Amino Acid Stable Nitrogen Isotope Ratios for Estimating Trophic Position in Marine Organisms. Oecologia 2015, 178 (3), 631-642. https://doi.org/10.1007/s00442-015-3305-7.

(66) Germain, L. R.; Koch, P. L.; Harvey, J.; McCarthy, M. D. Nitrogen Isotope Fractionation in Amino Acids from Harbor Seals: Implications for Compound-Specific Trophic Position Calculations. Mar. Ecol. Prog. Ser. 2013, 482, 265-277. https://doi.org/10.3354/meps10257.

(67) Rode, K. D.; Stricker, C. A.; Erlenbach, J.; Robbins, C. T.; Cherry, S. G.; Newsome, S. D.; Cutting, A.; Jensen, S.; Stenhouse, G.; Brooks, M.; Hash, A.; Nicassio, N. Isotopic Incorporation and the Effects of Fasting and Dietary Lipid Content on Isotopic Discrimination in Large Carnivorous Mammals. Physiol. Biochem. Zool. 2016, 89 (3), 182-197. https://doi.org/10.1086/686490.

(68) Rogers, M. C.; Peacock, E.; Simac, K.; O’Dell, M. B.; Welker, J. M. Diet of Female Polar Bears in the Southern Beaufort Sea of Alaska: Evidence for an Emerging Alternative Foraging Strategy in Response to Environmental Change. Polar Biol. 2015, 38 (7), 1035-1047. https://doi.org/10.1007/s00300-015-1665-4.

(69) Pinheiro, J.; Bates, D.; DebRoy, S.; Sarkar, D. nlme: Linear and Nonlinear Mixed Effects Models. $R$ package version 3.1-140. 2019, https://CRAN.R-project.org/package=nlme.

(70) Routti, H.; Aars, J.; Fuglei, E.; Hanssen, L.; Lone, K.; Polder, A.; Pedersen, Å. Ø.; Tartu, S.; Welker, J. M.; Yoccoz, N. G. Emission Changes Dwarf the Influence of Feeding Habits on Temporal Trends of Per- and Polyfluoroalkyl Substances in Two Arctic Top Predators. Environ. Sci. Technol. 2017, $51 \quad$ (20), 11996-12006. https://doi.org/10.1021/acs.est.7b03585.

(71) Lippold, A.; Bourgeon, S.; Aars, J.; Andersen, M.; Polder, A.; Lyche, J. L.; Bytingsvik, J.; Jenssen, B. M.; Derocher, A. E.; Welker, J. M.; Routti, H. Temporal Trends of Persistent Organic Pollutants in Barents Sea Polar Bears ( Ursus Maritimus) in Relation 
to Changes in Feeding Habits and Body Condition. Environ. Sci. Technol. 2019, 53 (2), 984-995. https://doi.org/10.1021/acs.est.8b05416.

(72) Zuur, A.; Ieno, E. N.; Walker, N.; Saveliev, A. A.; Smith, G. M. Mixed Effects Models and Extensions in Ecology with R; Statistics for Biology and Health; Springer-Verlag: New York, 2009.

(73) Jackson, A. L.; Inger, R.; Parnell, A. C.; Bearhop, S. Comparing Isotopic Niche Widths among and within Communities: SIBER - Stable Isotope Bayesian Ellipses in R. J. Anim. Ecol. 2011, 80 (3), 595-602. https://doi.org/10.1111/j.1365-2656.2011.01806.x.

(74) Gelman, A.; Hill, J. Data Analysis Using Regression and Multilevel/Hierarchical Models; Cambridge University Press, 2006.

(75) Freckleton, R. P. Dealing with Collinearity in Behavioural and Ecological Data: Model Averaging and the Problems of Measurement Error. Behav. Ecol. Sociobiol. 2011, 65 (1), 91-101. https://doi.org/10.1007/s00265-010-1045-6.

(76) Burnham, K. P.; Anderson, D. R. Model Selection and Multimodel Inference: A Practical Information-Theoretic Approach, 2nd ed.; Springer-Verlag: New York, 2002.

(77) Johnson, J. B.; Omland, K. S. Model Selection in Ecology and Evolution. Trends Ecol. Evol. 2004, 19 (2), 101-108. https://doi.org/10.1016/j.tree.2003.10.013.

(78) Grueber, C. E.; Nakagawa, S.; Laws, R. J.; Jamieson, I. G. Multimodel Inference in Ecology and Evolution: Challenges and Solutions. J. Evol. Biol. 2011, 24 (4), 699-711. https://doi.org/10.1111/j.1420-9101.2010.02210.x.

(79) Lukacs, P. M.; Burnham, K. P.; Anderson, D. R. Model Selection Bias and Freedman's Paradox. Ann. Inst. Stat. Math. 2010, 62 (1), 117-125. https://doi.org/10.1007/s10463009-0234-4.

(80) du Prel, J.-B.; Hommel, G.; Röhrig, B.; Blettner, M. Confidence Interval or P-Value? Dtsch. Ärztebl. Int. 2009, 106 (19), 335-339. https://doi.org/10.3238/arztebl.2009.0335.

(81) McMahon, K. W.; McCarthy, M. D. Embracing Variability in Amino Acid $\delta^{15} \mathrm{~N}$ Fractionation: Mechanisms, Implications, and Applications for Trophic Ecology. Ecosphere 2016, 7 (12), e01511. https://doi.org/10.1002/ecs2.1511.

(82) Lorrain, A.; Graham, B.; Ménard, F.; Popp, B.; Bouillon, S.; Van Breugel, P.; Cherel, Y. Nitrogen and Carbon Isotope Values of Individual Amino Acids: A Tool to Study Foraging Ecology of Penguins in the Southern Ocean. Mar. Ecol. Prog. Ser. 2009, 391, 293-306.

(83) Dale, J. J.; Wallsgrove, N. J.; Popp, B. N.; Holland, K. N. Nursery Habitat Use and Foraging Ecology of the Brown Stingray Dasyatis Lata Determined from Stomach Contents, Bulk and Amino Acid Stable Isotopes. Mar. Ecol. Prog. Ser. 2011, 433, 221236. https://doi.org/10.3354/meps09171.

(84) Choy, C. A.; Davison, P. C.; Drazen, J. C.; Flynn, A.; Gier, E. J.; Hoffman, J. C.; McClain-Counts, J. P.; Miller, T. W.; Popp, B. N.; Ross, S. W.; Sutton, T. T. Global Trophic Position Comparison of Two Dominant Mesopelagic Fish Families (Myctophidae, Stomiidae) Using Amino Acid Nitrogen Isotopic Analyses. PLOS ONE 2012, 7 (11), e50133. https://doi.org/10.1371/journal.pone.0050133.

(85) Hoen, D. K.; Kim, S. L.; Hussey, N. E.; Wallsgrove, N. J.; Drazen, J. C.; Popp, B. N. Amino Acid ${ }^{15} \mathrm{~N}$ Trophic Enrichment Factors of Four Large Carnivorous Fishes. J. Exp. Mar. Biol. Ecol. 2014, 453, 76-83. https://doi.org/10.1016/j.jembe.2014.01.006.

(86) Bradley, C. J.; Wallsgrove, N. J.; Choy, C. A.; Drazen, J. C.; Hetherington, E. D.; Hoen, D. K.; Popp, B. N. Trophic Position Estimates of Marine Teleosts Using Amino Acid Compound Specific Isotopic Analysis. Limnol. Oceanogr. Methods 2015, 13 (9), 476493. https://doi.org/10.1002/lom3.10041.

(87) Derocher, A. E.; Wiig, Ø.; Bangjord, G. Predation of Svalbard Reindeer by Polar Bears. Polar Biol. 2000, 23 (10), 675-678. https://doi.org/10.1007/s003000000138. 
(88) Stempniewicz, L.; Kidawa, D.; Barcikowski, M.; Iliszko, L. Unusual Hunting and Feeding Behaviour of Polar Bears on Spitsbergen. Polar Rec. 50 (02), 216-219.

(89) Macdonald, R. W.; Harner, T.; Fyfe, J. Recent Climate Change in the Arctic and Its Impact on Contaminant Pathways and Interpretation of Temporal Trend Data. Sci. Total Environ. 2005, 342 (1), 5-86. https://doi.org/10.1016/j.scitotenv.2004.12.059.

(90) Kallenborn, R.; MacDonald, R. Contaminant pathways and change in the cryosphere. In Snow, Water, Ice and Permafrost in the Arctic (SWIPA): Climate Change and the Cryosphere; Arctic Monitoring and Assessment Programme (AMAP), Oslo, Norway, 2011; pp 538.

(91) Ramsay, M. A.; Stirling, I. Reproductive Biology and Ecology of Female Polar Bears (Ursus Maritimus). J. Zool. 1988, 214 (4), 601-633. https://doi.org/10.1111/j.14697998.1988.tb03762.x.

(92) Divine, D. V.; Dick, C. Historical Variability of Sea Ice Edge Position in the Nordic Seas. J. Geophys. Res. Oceans 2006, 111 (C1). https://doi.org/10.1029/2004JC002851.

(93) Walter, N.; Gerland, S.; Granskog, M. A.; Jeffrey, R. K.; Haas, C.; Hovelsrud, G. R.; Kovacs, K. M.; Makshtas, A.; Michel, C.; Perovich, D.; Reist, J. D.; van Oort, B. O. H.. Sea Ice. In Snow, Water, Ice and Permafrost in the Arctic (SWIPA): Climate Change and the Cryosphere; Arctic Monitoring and Assessment Programme (AMAP), Oslo, Norway, 2011; pp 538.

(94) AMAP. Snow, Water, Ice and Permafrost in the Arctic (SWIPA) 2017. Arctic Monitoring and Assessment Programme (AMAP), Oslo, Norway. 2017, xiv + 269 pp.

(95) AMAP. AMAP Assessment Report: Arctic Pollution Issues; Technical Report. Arctic Monitoring and Assessment Programme (AMAP), Oslo, Norway. 1998.

(96) Wang, Z.; Cousins, I. T.; Scheringer, M.; Buck, R. C.; Hungerbühler, K. Global Emission Inventories for C4-C14 Perfluoroalkyl Carboxylic Acid (PFCA) Homologues from 1951 to 2030, Part I: Production and Emissions from Quantifiable Sources. Environ. Int. 2014, 70, 62-75. https://doi.org/10.1016/j.envint.2014.04.013.

(97) Wang, Z.; Boucher, J. M.; Scheringer, M.; Cousins, I. T.; Hungerbühler, K. Toward a Comprehensive Global Emission Inventory of C4-C10 Perfluoroalkanesulfonic Acids (PFSAs) and Related Precursors: Focus on the Life Cycle of C8-Based Products and Ongoing Industrial Transition. Environ. Sci. Technol. 2017, 51 (8), 4482-4493. https://doi.org/10.1021/acs.est.6b06191.

(98) Shindell, D. T.; Chin, M.; Dentener, F.; Doherty, R. M.; Faluvegi, G.; Fiore, A. M.; Hess, P.; Koch, D. M.; MacKenzie, I. A.; Sanderson, M. G.; Schultz, M. G.; Schulz, M.; Stevenson, D. S.; Teich, H.; Textor, C.; Wild, O.; Bergmann, D. J.; Bey, I.; Bian, H.; Cuvelier, C.; Duncan, B. M.; Folberth, G.; Horowitz, L. H.; Jonson, J.; Kaminski, J. W.; Marmer, E.; Park, R.; Pringle, K. J.; Shroeder, S.; Szopa, S.; Takemura, T.; Zeng, G.; Keating, T. J.; Zuber, A. A. Multi-Model Assessment of Pollution Transport to the Arctic. Atmos Chem Phys 2008, 8 (17), 5353-5372.

(99) Kwok, K. Y.; Yamazaki, E.; Yamashita, N.; Taniyasu, S.; Murphy, M. B.; Horii, Y.; Petrick, G.; Kallerborn, R.; Kannan, K.; Murano, K.; Lam, P. K. S. Transport of Perfluoroalkyl Substances (PFAS) from an Arctic Glacier to Downstream Locations: Implications for Sources. Sci. Total Environ. 2013, 447, 46-55. https://doi.org/10.1016/j.scitotenv.2012.10.091.

(100) Codling, G.; Halsall, C.; Ahrens, L.; Del Vento, S.; Wiberg, K.; Bergknut, M.; Laudon, H.; Ebinghaus, R. The Fate of Per- and Polyfluoroalkyl Substances within a Melting Snowpack of a Boreal Forest. Environ. Pollut. 2014, 191, 190-198. https://doi.org/10.1016/j.envpol.2014.04.032.

(101) Durner, G. M.; Douglas, D. C.; Nielson, R. M.; Amstrup, S. C.; McDonald, T. L.; Stirling, I.; Mauritzen, M.; Born, E. W.; Wiig, Ø.; DeWeaver, E.; Sereze, M. C.; Belikov, 
S. E.; Holland, M. H.; Mashlanik, J.; Aars, J.; Bailey, D. A.; Derocher, A. E. Predicting 21st-Century Polar Bear Habitat Distribution from Global Climate Models. Ecol. Monogr. 2009, 79 (1), 25-58. https://doi.org/10.1890/07-2089.1. 
767 Table 1. Estimated pollutant concentrations and ecological predictors in pelagic and coastal adult female polar bears from the Barents Sea (2011-

2018). Pelagic and coastal polar bears were compared using linear mixed-effect models with "sampling year" as a random factor.

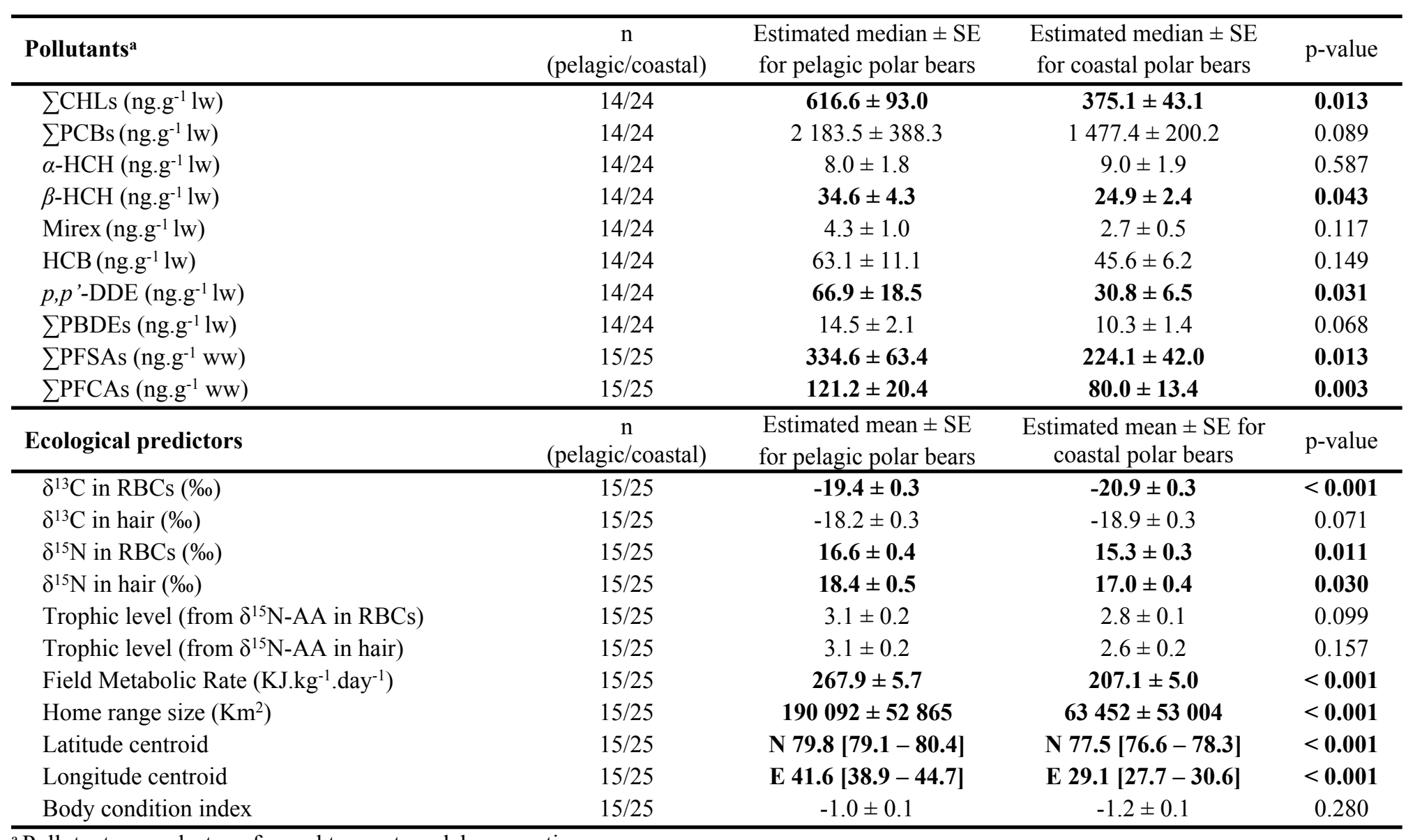

769 a Pollutants were ln-transformed to meet model assumptions

770 Significant differences are shown in bold

771 OCs and PBDEs have been measured in adipose tissue and PFASs in plasma 
Table 2. Estimated pollutant concentrations and body condition index $(\mathrm{BCI})$ in adult harp seals from the White Sea - Barents Sea stock $(\mathrm{n}=10)$ and Greenland Sea stock $(\mathrm{n}=10)$. White Sea - Barents Sea and Greenland Sea harp seals were compared using linear models. Values are expressed in ng. $\mathrm{g}^{-1} \mathrm{lw}$ for OCs and PBDEs and in ng. $\mathrm{g}^{-1} \mathrm{ww}$ for PFASs.

\begin{tabular}{lccc}
\hline Variables & $\begin{array}{c}\text { Estimated median } \pm \text { SE } \\
\text { for White Sea - Barents Sea harp seals }\end{array}$ & $\begin{array}{c}\text { Estimated median } \pm \text { SE } \\
\text { for Greenland Sea harp seals }\end{array}$ & p-value \\
\hline$\sum$ CHLs & $\mathbf{1 9 5 . 4} \pm \mathbf{2 5 . 2}$ & $\mathbf{1 2 7 . 4} \pm \mathbf{1 6 . 4}$ & $\mathbf{0 . 0 3 0}$ \\
$\sum$ PCBs & $\mathbf{3 6 2 . 6} \pm \mathbf{5 5 . 7}$ & $\mathbf{1 9 9 . 2} \pm \mathbf{3 0 . 6}$ & $\mathbf{0 . 0 1 3}$ \\
$\alpha-\mathrm{HCH}$ & $\mathbf{3 . 4} \pm \mathbf{0 . 3}$ & $\mathbf{5 . 1} \pm \mathbf{0 . 5}$ & $\mathbf{0 . 0 0 9}$ \\
Mirex & $3.9 \pm 2.0$ & $2.2 \pm 1.1$ & 0.431 \\
HCB & $\mathbf{5 9 . 4} \pm \mathbf{1 0 . 7}$ & $\mathbf{3 5 . 3} \pm \mathbf{6 . 4}$ & $\mathbf{0 . 0 5 5}$ \\
$p, p$ '-DDE & $\mathbf{2 6 5 . 8} \pm \mathbf{4 0 . 4}$ & $\mathbf{1 5 6 . 5} \pm \mathbf{2 3 . 8}$ & $\mathbf{0 . 0 2 4}$ \\
$\sum$ PBDEs & $3.8 \pm 0.5$ & $3.6 \pm 0.5$ & 0.763 \\
$\sum$ PFSAs & $\mathbf{3 9 . 7} \pm \mathbf{6 . 5}$ & $\mathbf{2 1 . 1} \pm \mathbf{3 . 4}$ & $\mathbf{0 . 0 1 3}$ \\
$\sum$ PFCAs & $20.6 \pm 2.9$ & $18.0 \pm 2.5$ & 0.504 \\
BCI & $0.6 \pm 0.1$ & $0.7 \pm 0.1$ & 0.210 \\
\hline
\end{tabular}

775 Pollutants and BCI were ln-transformed to meet model assumptions

776 Significant differences are shown in bold

777 OCs and PBDEs have been measured in adipose tissue and PFASs in plasma/serum 
778 Figure 1. Map of the study area including the tracks of 40 adult female polar bears. The tracks

779 are color-coded according to their ecotype: pelagic $(n=15$ in blue) or coastal ( $n=25$ in orange).

780 The staple black line represents the coastal region around the Svalbard area. The insert shows

781 the location of the Svalbard Archipelago (in red).

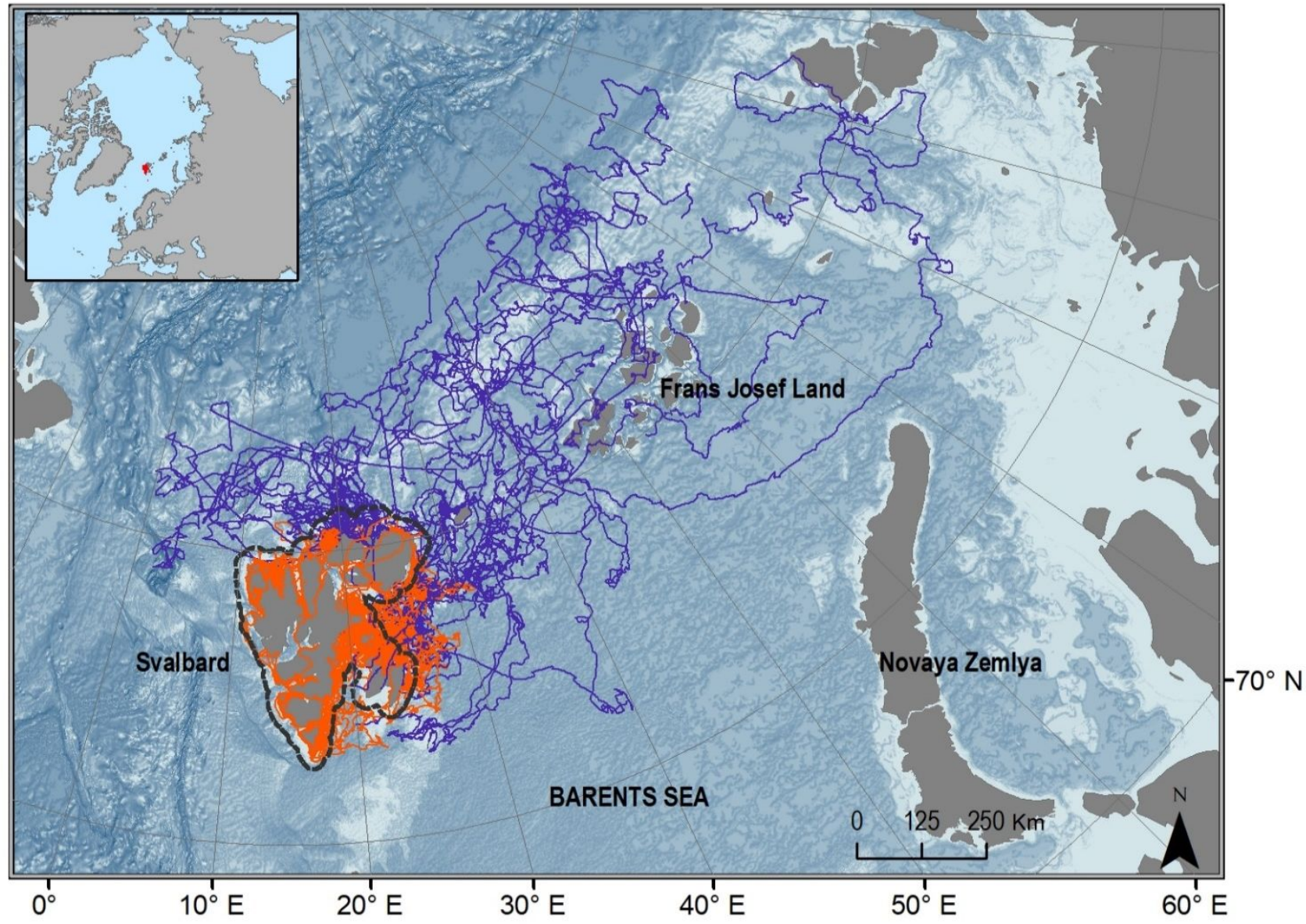


783 Figure 2. (A) Isotopic niche width (inferred from $\delta^{13} \mathrm{C}$ and $\delta^{15} \mathrm{~N}$ in RBCs) illustrated by 784 standard ellipses (containing $\sim 95 \%$ of the data and computed with "SIBER" R-package), for 785 both pelagic (blue point) and coastal (orange triangle) Barents Sea polar bears $(n=40$ adult 786 females). (B) Comparison of the standard ellipse area (SEA) according to the ecotype. SEA $\mathrm{A}_{\mathrm{b}}$ is 787 illustrated with black point and $\mathrm{SEA}_{\mathrm{c}}$ with red cross.

788
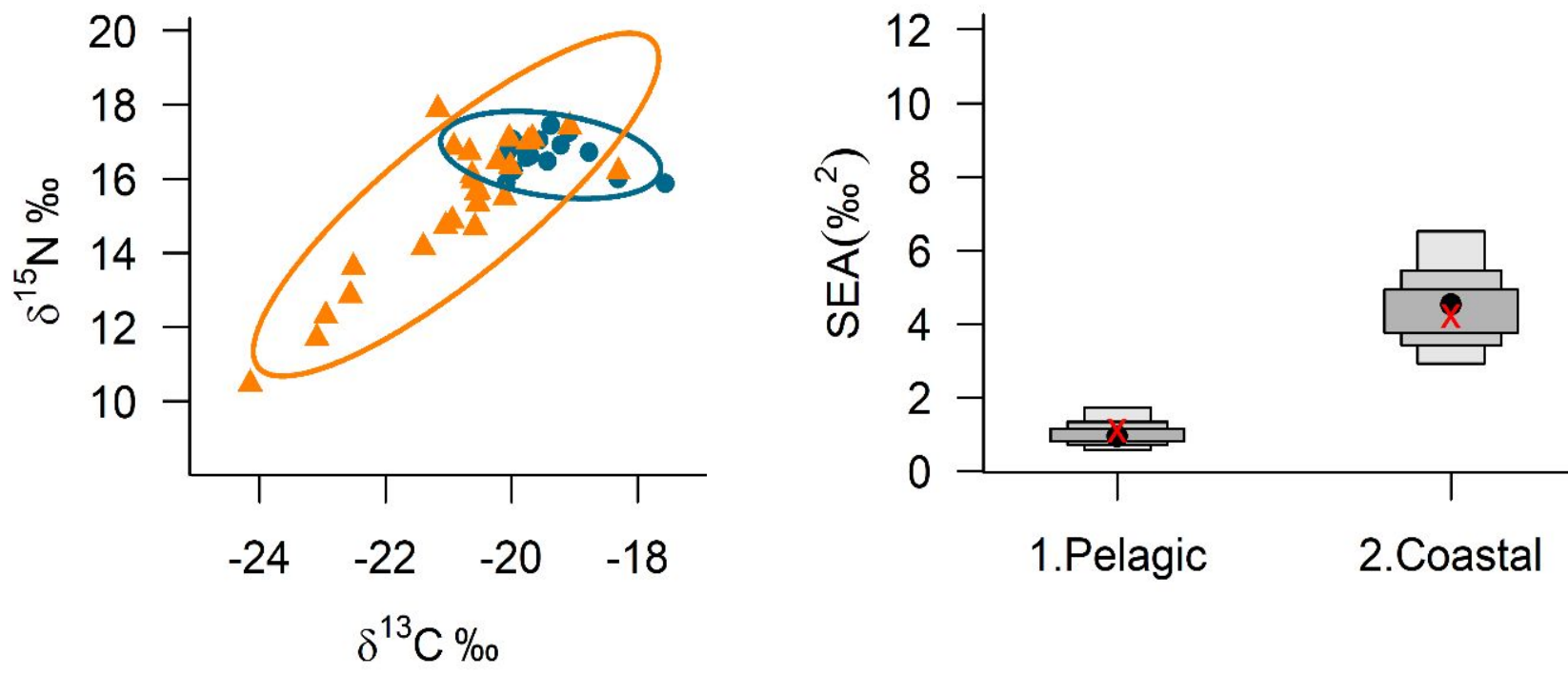
789 Figure 3. Effects size of $\delta^{13} \mathrm{C}$ (in RBCs and hair), $\delta^{15} \mathrm{~N}$ (in RBCs and hair), trophic level (from $790 \quad \delta^{15} \mathrm{~N}-\mathrm{AA}$ in RBCs and hair), field metabolic rate (FMR), latitude and longitude centroids, and 791 body condition index (BCI) on pollutant levels in adult female polar bears from the Barents Sea 792 (2011-2018; $\mathrm{n}=38$ for OCs/ PBDEs and $\mathrm{n}=40$ for PFASs). The figures illustrates model 793 averaging outputs (conditional averaged estimates and 95\% confidence interval) from the 794 selected models. Values of pollutants were $\ln$-transformed 

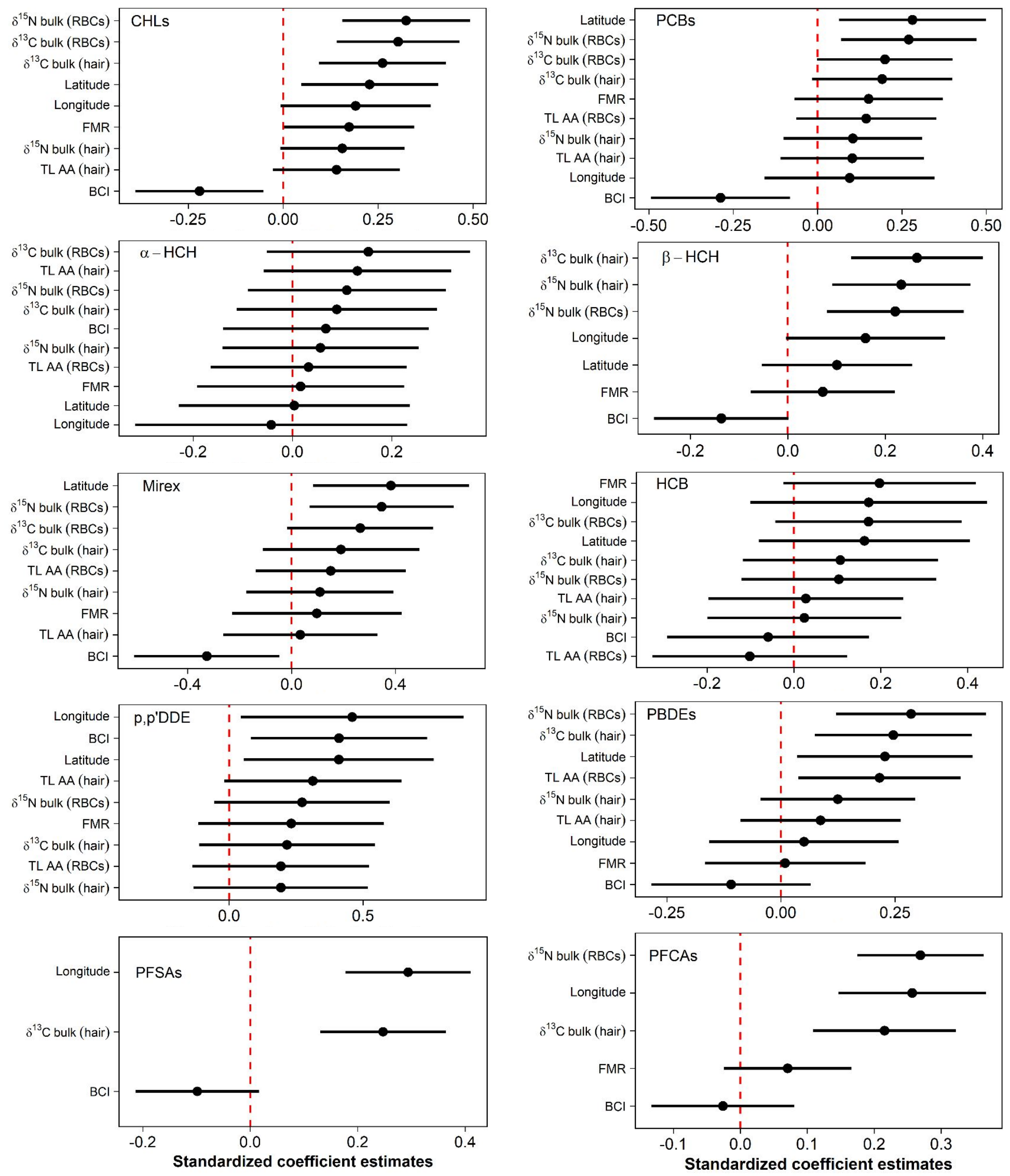